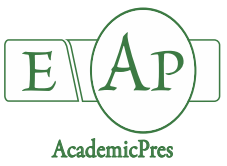

Kanatas P et al. (2020)

Notulae Botanicae Horti Agrobotanici Cluj-Napoca 48(1):329-341

DOI: $10.15835 /$ nbha48111823

Research Article

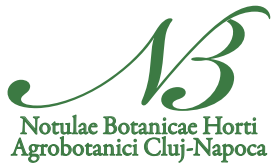

\title{
Yield, quality and weed control in soybean crop as affected by several cultural and weed management practices
}

\author{
Panagiotis KANATAS ${ }^{1 *}$, Ilias TRAVLOS ${ }^{2}$, \\ Panayiota PAPASTYLIANOU², Ioannis GAZOULIS ${ }^{2}$, \\ Ioanna KAKABOUKI ${ }^{2}$, Anastasia TSEKOURA ${ }^{2}$ \\ ${ }^{1}$ Agricultural Cooperative of Mesolonghi-Nafpaktia, 30200 Mesolonghi, Greece; pakanatas@gmail.com (*correspondingauthor) \\ ${ }^{2}$ Agricultural University of Athens, Department of Crop Science, 75 Iera Odos str., 11855 Athens, \\ Greece;travlos@aua.gr;ppapastyl@aua.gr;giangazoulis@gmail.com; i.kakabouki@gmail.com;natasa_tse@hotmail.com
}

\begin{abstract}
In the field of Agricultural University of Athens, the effects of false seedbed technique, stale seedbed, chemical and ecologically based control on weed growth and soybean yield were evaluated (2019). The experimental treatments were: normal seedbed, normal seedbed along with pre-emergence chemical control, false seedbed, stale seedbed with glyphosate and stale seedbed with pelargonic acid. In the plots of normal seedbed along with pre-emergence chemical control, pendimethalin was applied at rate of $1560 \mathrm{~g}$ a.i. ha ${ }^{-1}$. In the plots of stale seedbed with glyphosate, glyphosate was applied at a rate of $2160 \mathrm{~g}$ a.e. ha $^{-1}$ and in the plots of stale seedbed with pelargonic acid, pelargonic acid was applied at a rate of $31020 \mathrm{~g}$ a.i. $\mathrm{ha}^{-1}$. The experiment was conducted in a randomized complete block design with three replicates. The results revealed that stale seedbed combined either with glyphosate or pelargonic acid application reduced annual weeds' density by 94 and $95 \%$ as compared to normal seedbed. Stale seedbed along with pelargonic acid reduced the density of perennial weeds by 36,38 and $41 \%$ as compared to the combination of normal seedbed and pre-emergence chemical control, normal seedbed and false seedbed, respectively. The application of glyphosate in stale seedbed plots was also effective against perennial weeds. It was also observed that stale seedbed along with glyphosate increased soybean seed yield by 17,19 and $35 \%$ as compared to the combination of normal seedbed and pendimethalin application, false seedbed and normal seedbed, respectively. Beneficial were also the effects of the combination of stale seedbed and pelargonic acid not only on soybean seed yield but also on soybean protein content. Further research is needed in order to investigate the role of false and stale seedbeds as integrated weed management practices in various crops and under different soil and climatic conditions. Research is also needed to evaluate pelargonic acid for weed control in stale seedbeds since it is an eco-friendly herbicide with no restrictions for organic farming.
\end{abstract}

Keywords: false seedbed; normal seedbed; pelargonic acid; pre-emergence chemical control; soybean; stale seedbed

Abbreviations: NSB-normal seedbed; PDMTH- pendimethalin; FSB-false seedbed; SSB-stale seedbed; GLY-glyphosate; PA-pelargonic acid 


\section{Introduction}

The soybean crop is one of the most important crops worldwide with USA, Brazil and Argentina being the most dominant soybean producers. FAO recorded that during 2018, 2835295 tonnes of soybean were produced in 955670 hectares in European Union whereas in Greece 9490 tonnes were produced in 3370 hectares (FAO, 2018). Soybean seeds contain about 38\% protein and 18\% oil. Due to its high protein level, about $98 \%$ of the soybean meal is used in livestock and aquaculture feeds. Moreover, the extracted oil is used in making numerous processed food products (Hartman et al., 2011). Weeds compete with soybean for light, water, and nutrients, and can drastically reduce soybean quality and yield. Globally, in soybean production, weeds cause the greatest yield loss. And there is evidence on a global basis, $37 \%$ of attainable soybean production is endangered by weed competition (Oerke, 2006).

Since weed seed banks are the primary source of persistent weed infestations in agricultural fields (Cousens and Mortimer, 1995) it is more preferable to focus management efforts on depleting the dynamics of the seed resource stock in the soil through time rather than viewing weeds just as an annual threat to agricultural production (Jones and Medd, 2000). Methods providing weed seed bank depletion are the false seedbed technique and the stale seedbed technique.

In the case of false seedbed, weed control is achieved by shallow tillage operations. Given that the maximum depth of emergence for most cropping weeds is $5 \mathrm{~cm}$, if tillage overpasses this boundary, nondormant seeds from deeper soil profiles are placed in germinable superficial soil positions. Re-tillage must be as shallow as $2 \mathrm{~cm}$ (Merfield, 2013). False seedbed has shown great potential as weed management practice of in winter crops such as barley especially when combined with post-emergence chemical control (Kanatas et al., 2020) and also in summer crops such as rice (Sindu et al., 2010). In stale seedbeds weed control is mainly depended on the application of a non-selective herbicide. The main purpose of this system is to stimulate weed emergence before crop sowing by means of early soil tillage from several days or weeks prior to sowing and killing using broad spectrum herbicides such as glyphosate (Barberi, 2003). Efficacy of stale seedbed preparation systems in terms of weed suppression has been reported in important crops such as soybean, cotton, wheat, rice and also in vegetable crops (Bruff and Shaw, 1992; Lonsbary et al., 2003; Sharma et al., 2004, Kumar et al., 2005; Veeramani et al., 2006; Riemens et al., 2007).

Glyphosate is a wide spectrum herbicide with less hazardous properties to environment and its application in stale seedbeds has given promising results as it was indicated by earlier studies carried out in soybean crop (Bruff and Shaw, 1992; Oliver et al., 1993; Lanie et al., 1994). Pelargonic acid, a naturally occurring nine-carbon fatty acid, causes extremely rapid and nonselective desiccation of green tissue (Pline et al., 2000). One of the most controversial societal issues in the European Union (EU) may be the case surrounding re-registration of glyphosate (Székács and Darvas, 2018). Given that the use of glyphosate may be banned in the future, the efficacy of alternative weed control methods should be evaluated in stale seedbeds. Pelargonic acid is a non-selective herbicide, its potential role as weed control method in stale seedbeds should be investigated since it is an eco-friendly herbicide with no restrictions in organic crop production.

The main objectives of the current study were to evaluate the effects of false and stale seedbed on weed flora, soybean yield and protein content and investigate if pelargonic acid can provide efficient weed control in a stale seedbed. Another target of the present study was to compare the efficacy of false and stale seedbed as weed management practices with the efficacy of the application of pre-emergence chemical control using a soil herbicide such as pendimethalin. 


\section{Materials and Methods}

\section{Description of the experimental treatments}

The soil of the experimental field is clay loam (CL) with pH value of 7.29 (Table 1). The experiment was conducted under typical climatic conditions for Greece (Table 2). The experiment was carried out in a randomized complete block design with three replicates and five treatments. The size of each plot was $3 \mathrm{~m} \times 4$ $\mathrm{m}$. The five experimental treatments were: normal seedbed, normal seedbed along with pendimethalin spray as pre-emergence chemical control, false seedbed, stale seedbed along with glyphosate spray for and stale seedbed along with pelargonic acid spray. Seeding rate of soybean was 300,000 seeds ha ${ }^{-1}$ and the chosen row spacing was $38 \mathrm{~cm}$. Seedbed preparation was carried out by ploughing at depth of $20 \mathrm{~cm}$ in May 3 . In the plots of normal seedbed treatment, no weed control method followed seedbed preparation. Sowing in the plots of normal seedbed treatment was carried out in May 9. In the plots of normal seedbed treatment, no weed control method followed seedbed preparation. In the plots of normal seedbed along with pre-emergence chemical control, pendimethalin was applied at rate of $1560 \mathrm{~g}$ a.i. ha ${ }^{-1}$. The plots where false seedbed and the two stale seedbed treatments were adopted were kept unsown for 14 days. Irrigation in the meantime was applied every day to stimulate weed seedlings' emergence. Then, in the plots of false seedbed the emerged weeds were controlled by shallow tillage and soybean was sown in May 25. In the plots of stale seedbed by glyphosate, glyphosate was applied in May 21 at rate of $2160 \mathrm{~g}$ a.e. ha ${ }^{-1}$ and soybean were sown in May 25. In the plots of stale seedbed by pelargonic acid, pelargonic acid was applied at rate of $31020 \mathrm{~g}$ a.i. ha ${ }^{-1}$ and soybean were sown in May 25. A pressure sprayer equipped with 5 flat-fan nozzles was used for the applications of herbicides at a water volume of $300 \mathrm{~L} \mathrm{ha}^{-1}$ at 3 bars pressure.

Table 1. Soil conditions in the experimental field of Agricultural University of Athens

\begin{tabular}{|c|c|}
\hline Parameter & Value \\
\hline $\mathrm{CaCO}_{3}$ & $15.99 \%$ \\
\hline Organic matter $^{-}$ & $2.37 \%$ \\
\hline $\mathrm{NO}_{3}^{-}$ & $104.3 \mathrm{ppm}$ \\
\hline $\mathrm{P}^{-}$Olsen $)$ & $9.95 \mathrm{ppm}$ \\
\hline $\mathrm{Na}^{+}$ & $110 \mathrm{ppm}$ \\
\hline $\mathrm{pH}$ & 7.29 \\
\hline Soil type & Clay Loam $(\mathrm{CL})$ \\
\hline
\end{tabular}

Table 2. Mean maximum, minimum temperature and rainfall values recorded for each month during the experimental period

\begin{tabular}{|c|c|c|c|}
\hline Month & $\operatorname{Max} \mathrm{T}\left({ }^{\circ} \mathrm{C}\right)$ & $\operatorname{Min} \mathrm{T}\left({ }^{\circ} \mathrm{C}\right)$ & Rainfall $(\mathrm{mm})$ \\
\hline May & 24.2 & 15.8 & 0.07 \\
\hline June & 31.0 & 22.7 & 0.09 \\
\hline July & 32.6 & 23.8 & 0.03 \\
\hline August & 33.6 & 25.6 & 0 \\
\hline September & 29.0 & 21.0 & 0.16 \\
\hline
\end{tabular}

\section{Description of the observations}

For the evaluation of the effect of experimental treatments on annual and perennial weed species density, the number of plants per unit area was measured. After weed emergence, three $0.1 \mathrm{~m}^{2}$ quadrats were permanently marked in each plot. Quadrats were placed away from plot margins and in areas with uniform weed flora. Annual weeds were counted in each quadrat at 30 days after the day in which sowing was carried out in the plots of normal seedbed. The number of plants counted per $0.1 \mathrm{~m}^{2}$ was annualized to number of plants per $1 \mathrm{~m}^{2}$. The same course of action was followed for the measurement of the density of perennial weeds 
332

which was carried out at 35 days after the day in which sowing was carried out in the plots of normal seedbed. For the evaluation of the effect of experimental treatments on total weed dry weight, aboveground biomass was harvested from each quadrat by clipping plants at a height of 3 to $5 \mathrm{~cm}$. The harvested vegetation was dried for 48 hours at $60{ }^{\circ} \mathrm{C}$. Afterwards, total weed dry weight per $0.1 \mathrm{~m}^{2}$ was measured and the recorded value was annualized to total weed dry weight per $1 \mathrm{~m}^{2}$. The measurement of total weed dry weight was carried out at 45 days after the day in which sowing was carried out in the plots of normal seedbed. Soybean was harvested in September 12. Number of pods per unit area, seeds per pod and weight of 1000 seeds were measured after harvest for the evaluation of soybean seed yield. The protein content of the harvested seeds was also measured by using Kjeldahl protein analysis.

\section{Statistical analysis}

Barlett's chi-square test for homogeneity of variance was tested and all data were subjected to Analysis of Variance (ANOVA) using STATGRAPHICS Centurion XVI. The effects of the experimental treatments on annual and perennial weeds' density, total weed dry weight per unit area, soybean seed yield and protein content were tested using ANOVA at a $=5 \%$ significance level.

\section{Results}

\section{Effects of the experimental treatments on the density of annual weeds}

The dominant annual weeds emerged in the experimental area were redroot pigweed (A. retroflexus) and common purslane ( $P$. oleracea). Analysis of variance revealed that the density of annual weeds was significantly affected by the experimental treatments (Table 3). All the treatments provided effective control of annual weeds as compared to normal seedbed. The application of pendimethalin as pre-emergence chemical control resulted in $96 \%$ control of annual weeds as compared to normal seedbed treatment. The density of annual weeds recorded in the false seedbed plots was by $89 \%$ lower than the corresponding value recorded in normal seedbed plots. The application of either glyphosate or pelargonic acid in stale seedbed plots decreased annual weeds' density by approximately $95 \%$ as compared to normal seedbed without any herbicide application (Figure $1)$.

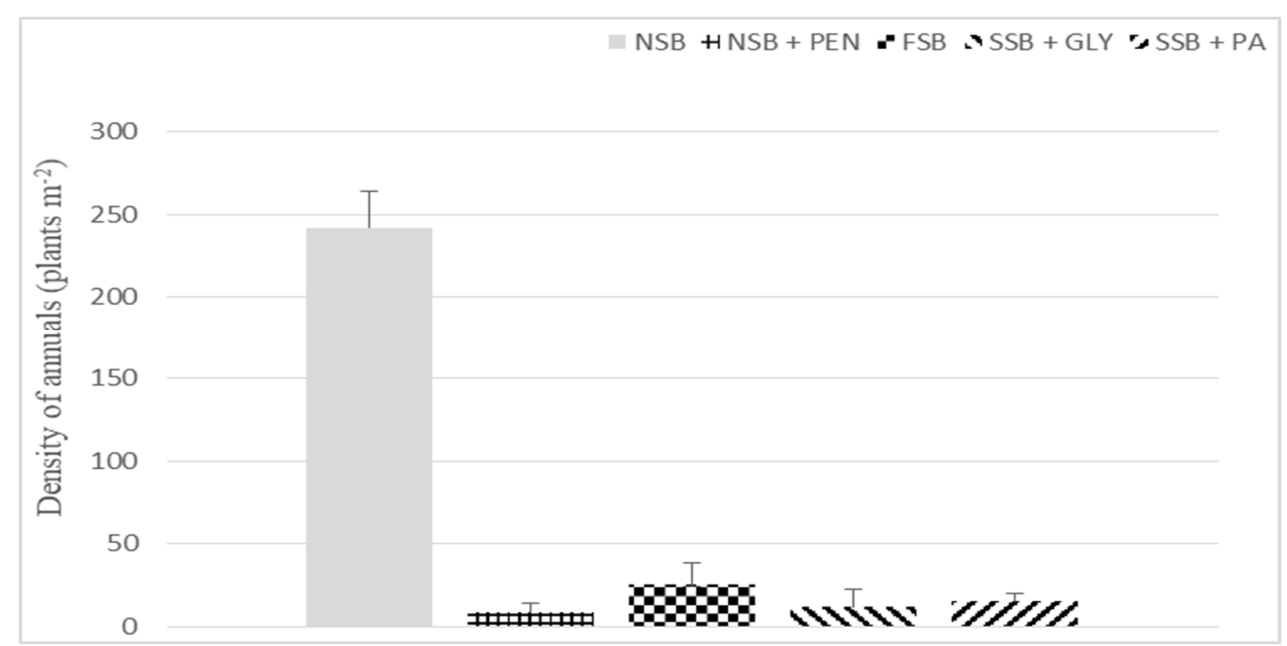

Figure 1. Density of annual weeds (plants $\mathrm{m}^{-2}$ ) emerged in the experimental area. The measurement was carried out 30 days after sowing in the plots of normal seedbed. Vertical bars denote standard errors of the means 
Table 3. Analysis of Variance (ANOVA) for the density of annual weeds (plants $\mathrm{m}^{-2}$ ) emerged in the experimental area. The measurement was carried out 30 days after sowing in the plots of normal seedbed

\begin{tabular}{|c|c|c|c|c|c|}
\hline Source & Df & Ss & Ms & F-Ratio & P-Value \\
\hline Treatment & 4 & 123773.0 & 30943.3 & 253.46 & $0.0000^{* * *}$ \\
\hline Residual & 8 & 976.667 & 122.083 & & \\
\hline Total & 14 & 125473.0 & & & \\
\hline
\end{tabular}

\section{Effects of the experimental treatments on the density of perennial weeds}

The dominant perennial weeds were field bindweed (Convolvulus arvensis L.) and purple nutsedge (Cyperus rotundus $\mathrm{L}$.) whereas the presence of the biennial species Malva sylvestris ( $\mathrm{L}$.) was also observed in the experimental area. The different treatments did put a significant effect on the density of perennial weeds (Table 4). The population of perennial weeds was not affected by pre-emergence chemical control in normal seedbed plots. Similar was the inefficacy of false seedbed with shallow tillage as weed control practice since it did not reduce perennial weeds' density in comparison to normal seedbed treatment. However, $38 \%$ lower density was recorded when the combination of stale seedbed technique and pelargonic acid spray was adopted instead of normal seedbed. Even greater was the control (72\%) of perennials under the combination of stale seedbed and glyphosate spray in comparison to normal seedbed treatment. Stale seedbed with glyphosate spray resulted in 71 and $74 \%$ lower density of perennial weeds as compared to normal seedbed along with pre-emergence control and false seedbed, respectively. Glyphosate application in stale seedbed plots was proven to be superior to pelargonic acid. However, pelargonic acid was more efficient than other treatments against perennials and its application in stale seedbed plots leaded to some promising results. Stale seedbed along with pelargonic acid spray as weed control method was by 36 and $41 \%$ more effective against perennial weeds as compared to the combination of normal seedbed along with pendimethalin spray and false seedbed treatment, respectively (Figure 2).

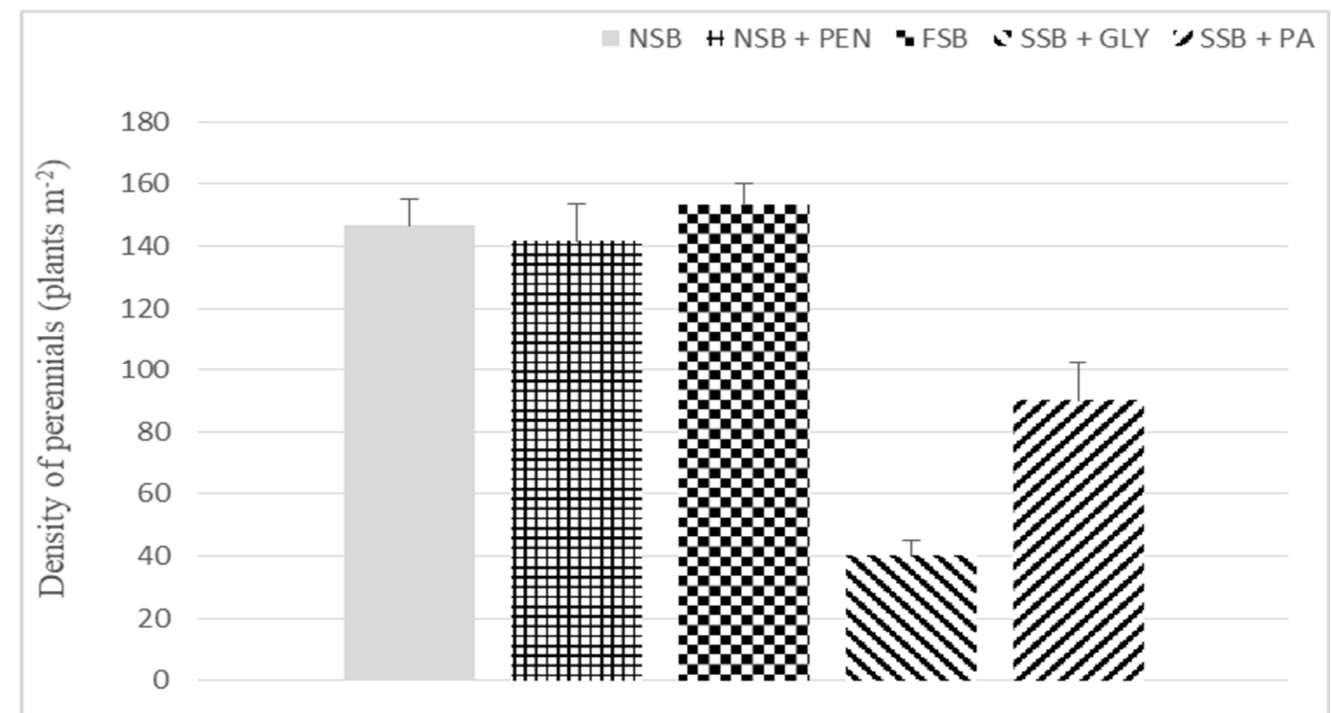

Figuri 2. Density of perennial weeds (plants $\mathrm{m}^{-2}$ ) emerged in the experimental area. The measurement was carried out 35 days after sowing in the plots of normal seedbed. Vertical bars denote standard errors of the means 
Table 4. Analysis of Variance (ANOVA) for the density of perennial weeds (plants $\mathrm{m}^{-2}$ ) emerged in the experimental area. The measurement was carried out 35 days after sowing in the plots of normal seedbed

\begin{tabular}{|c|c|c|c|c|c|}
\hline Source & Df & Ss & Ms & F-Ratio & P-Value \\
\hline Treatment & 4 & 28293.3 & 7073.33 & 23.71 & $0.0002^{* * *}$ \\
\hline Residual & 8 & 2386.67 & 298.333 & & \\
\hline Total & 14 & 30943.3 & & & \\
\hline
\end{tabular}

\section{Effects of the experimental treatments on total weed dry weight}

The effects of the experimental treatments on total weed dry weight per unit area were proven as statistically significant as it was indicated from Analysis of Variance (Table 5). In normal seedbed plots total weed dry weight per unit area was by $59 \%$ higher than the value recorded in false seedbed plots and by $64 \%$ than the corresponding value recorded in plots where normal seedbed was followed by the application of pendimethalin as pre-emergence chemical control. The combination of stale seedbed and pelargonic acid was even more effective, since, this treatment decreased total weed dry weight by 58 and $83 \%$ as compared to false seedbed treatment and normal seedbed treatment, respectively. Total weed dry biomass was by $93 \%$ lower in plots where stale seedbed was combined with glyphosate application than the corresponding value recorded in normal seedbed plots. In addition, stale seedbed along with glyphosate application as weed control method decreased total weed dry weight by 81 and $83 \%$ in comparison to the combination of normal seedbed and pendimethalin application and false seedbed treatment, respectively (Figure 3 ).

\section{Effects of the experimental treatments on soybean seed yield}

Data as derived from ANOVA, revealed that the adoption of the different treatments did affect soybean seed yield at a significant point (Table 6). Stale seedbed along with pelargonic acid application increased soybean yield by 10,12 and $29 \%$ in comparison to normal seedbed along with pendimethalin application, false seedbed treatment and normal seedbed treatment, respectively. Similarly, the combination of stale seedbed and glyphosate spray resulted in 17,19 and $35 \%$ higher seed yield as compared to the combination of normal seedbed along with pre-emergence chemical control, false seedbed treatment and normal seedbed treatment, respectively. In stale seedbed plots, glyphosate spray leaded to higher seed yield than pelargonic acid spray but the difference was slight and not proven as statistically significant. Moreover, false seedbed increased soybean productivity by $19 \%$ as compared to normal seedbed whereas in plots of normal seedbed the application of pendimethalin for pre-emergence weed control leaded to $21 \%$ higher yield (Figure 4 ).

\section{Effects of the experimental treatments on soybean protein content}

Regarding soybean protein content, it was significantly affected by the five different treatments as it was shown from analysis of variance (Table 7). Adopting false seedbed technique instead of normal seedbed preparation resulted in $14 \%$ higher protein content whereas the application of pendimethalin increased soybean protein content by $16 \%$ in plots of normal seedbed. Applying glyphosate spray in stale seedbed plots leaded to 12 and $26 \%$ higher protein content than adopting false seedbed treatment and normal seedbed treatment, respectively. Moreover, it was observed that stale seedbed along with glyphosate increased also soybean protein by $12 \%$ as compared to normal seedbed with pre-emergence weed control. The combination of stale seedbed and pelargonic acid gave also promising results since its adoption resulted in approximately 7 and $20 \%$ higher soybean protein content as compared to false seedbed treatment and normal seedbed treatment, respectively (Figure 5). 
Table 5. Analysis of Variance (ANOVA) for total weed dry weight per unit area $\left(\mathrm{g} \mathrm{m}^{-2}\right)$. The measurement was carried out 45 days after sowing in the plots of normal seedbed

\begin{tabular}{|c|c|c|c|c|c|}
\hline Source & Df & Ss & Ms & F-Ratio & P-Value \\
\hline Treatment & 4 & $3.4405 \times 10^{-6}$ & 860126.0 & 39.15 & $0.0000^{* * *}$ \\
\hline Residual & 8 & 175761.0 & 21970.1 & & \\
\hline Total & 14 & $3.70835 \times 10^{-6}$ & & & \\
\hline
\end{tabular}

Note: ${ }^{* * *}$ denotes significant differences with P-Value $<0.001$

Table 6. Analysis of Variance (ANOVA) for soybean seed yield $\left(\mathrm{kg} \mathrm{ha}^{-1}\right)$

\begin{tabular}{|c|c|c|c|c|c|}
\hline Source & Df & Ss & Ms & F-Ratio & P-Value \\
\hline Treatment & 4 & $1.79132 \times 10^{-6}$ & 447830.0 & 7.62 & $0.0078^{* *}$ \\
\hline Residual & 8 & 470469.0 & 58808.7 & & \\
\hline Total & 14 & $2.30028 \times 10^{-6}$ & & & \\
\hline
\end{tabular}

Note: ${ }^{* *}$ denotes significant differences with P-Value $<0.01$

Table 7. Analysis of Variance (ANOVA) for soybean protein content (\%)

\begin{tabular}{|c|c|c|c|c|c|}
\hline Source & Df & Ss & Ms & F-Ratio & P-Value \\
\hline Treatment & 4 & 186.933 & 46.7333 & 4.02 & $0.0448^{*}$ \\
\hline Residual & 8 & 93.0667 & 11.6333 & & \\
\hline Total & 14 & 295.6 & & & \\
\hline
\end{tabular}

Note: ${ }^{*}$ denotes significant differences with P-Value $<0.05$

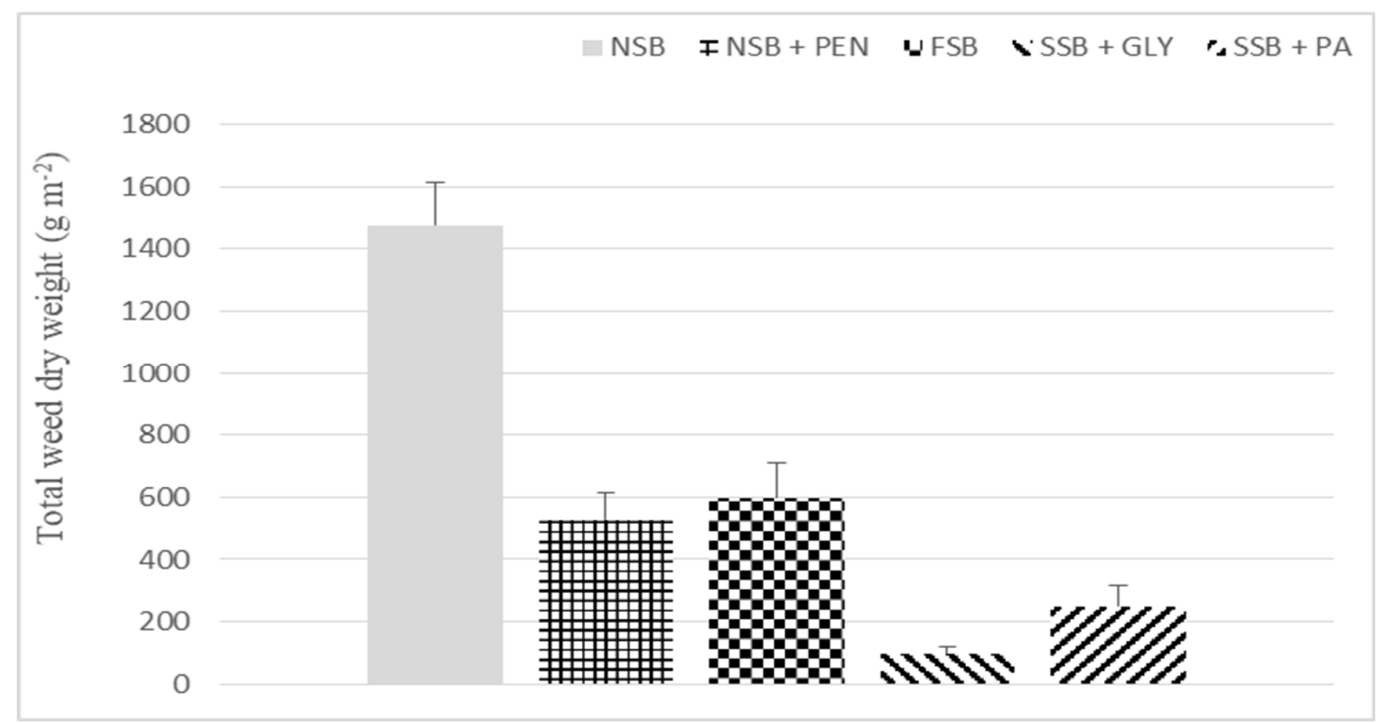

Figure 3. Total weed dry weight per unit area $\left(\mathrm{g} \mathrm{m}^{-2}\right)$. The measurement was carried out 45 days after sowing in the plots of normal seedbed. Vertical bars denote standard errors of the means 


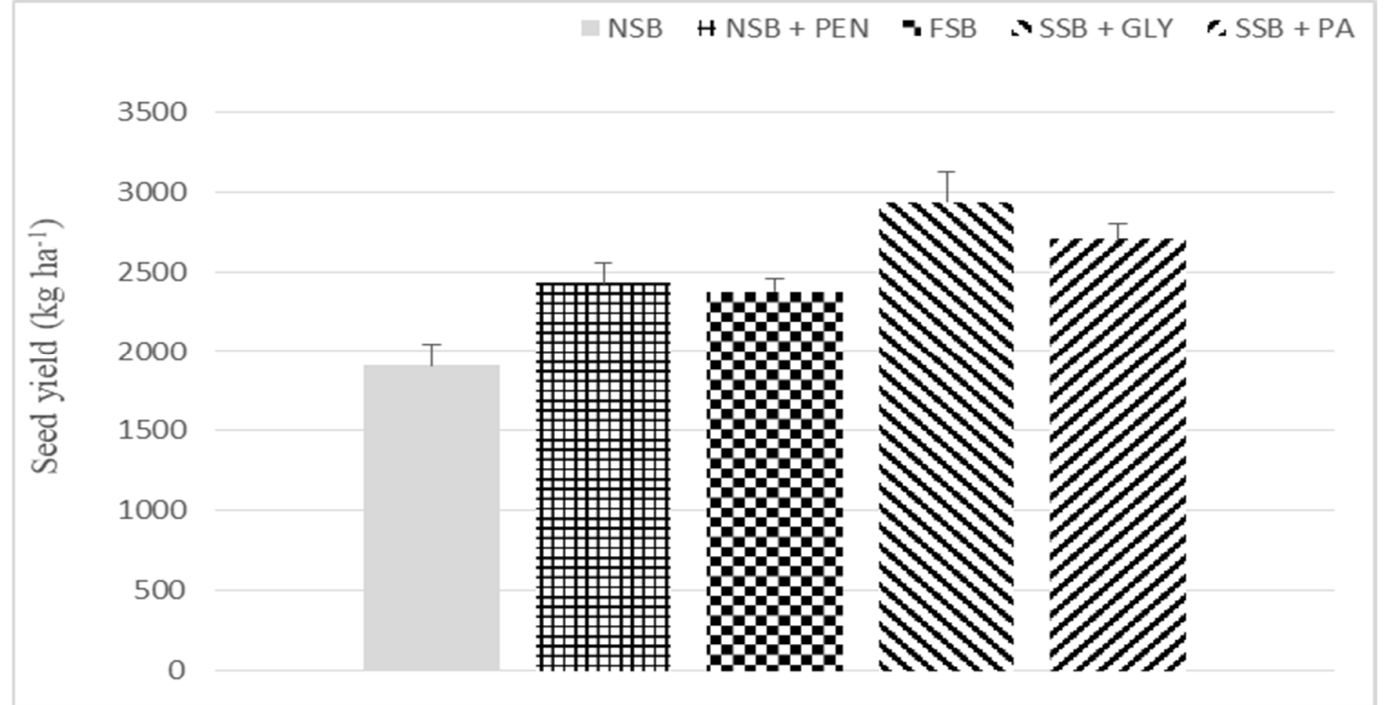

Figure 4. Soybean seed yield $\left(\mathrm{kg} \mathrm{ha}^{-1}\right)$ for the several treatments. Vertical bars denote standard errors of the means

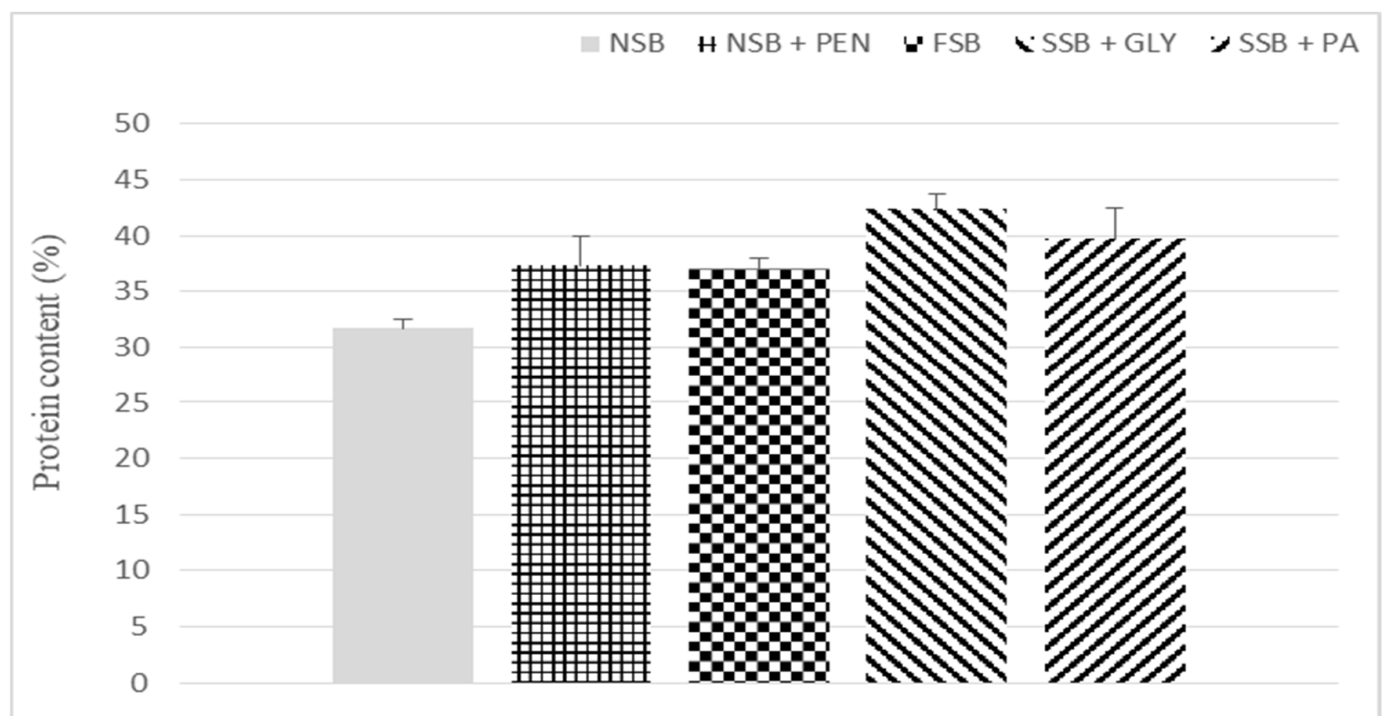

Figure 5. Soybean protein content (\%) for the several treatments. Vertical bars denote standard errors of the means

\section{Discussion}

\section{Effects of the experimental treatments on major weed species densities and total weed dry weight}

The results of the present study revealed that stale seedbed by applying glyphosate to control emerged weeds can be an effective weed control method against both annual and perennial weeds. Stale seedbed by glyphosate spray at rate of $2160 \mathrm{~g}$ a. e. $\mathrm{ha}^{-1}$ reduced the density of perennials as compared to normal seedbed treatment and this result is in common direction with the findings of other scientists who evaluated the stale seedbed along with non-selective herbicides as weed management method in soybean. For instance, Lanie et al. (1994) noticed that during the first year of their experiment, control of perennial weed species belonging to Convolvulaceae family was recorded at 80,85 and $90 \%$ in stale seedbed plots with glyphosate applied at rates of 
560, 840 and $1120 \mathrm{~g}$ a.i. ha ${ }^{-1}$, respectively, as compared to non-treated check plots. Hydrick and Shaw (1995) also found that for stale seedbed along with glyphosate applied at $420 \mathrm{~g}$ a.i. ha ${ }^{-1}$, control of Ipomoea lacunosa (L.) and Senna obtusifolia (L.) was recorded at 88 and $90 \%$ as compared to untreated check plots. In the experimental field where the current study was carried out, one of the major perennial species emerged was purple nutsedge (C. rotundus). Stale seedbed and glyphosate provided increased control of perennial weeds including purple nutsedge as compared to the combination of normal seedbed and pendimethalin spray at 1560 $\mathrm{g}$ a. i. ha ${ }^{-1}$. This finding is in agreement with the results of another study carried out in cotton crop. Purple nutsedge cover was $56 \%$ lower in plots where stale seedbed was combined with glyphosate as compared to the value recorded in plots of normal seedbed preparation along with trifluralin incorporation at $960 \mathrm{~g}$ a. i. ha ${ }^{-1}$ one day before sowing (Dogan et al., 2009). Stale seedbed along glyphosate applications was also proven to be an effective strategy against purple nutsedge in Okra crop (Abelmoschus esculentus (L.) Moench.) (Ameena et al., 2006).

The current study revealed also that forming a false seedbed and controlling the emerged weeds by shallow tillage operations can also be an effective control method of annual weed species such as redroot pigweed and common purslane. False seedbed by cultivation has also been reported to decrease weed density and total weed dry weight in finger millet (Eleusine coracana Gaertn.) (Patil et al., 2013). The results of this and other earlier studies have pointed out the importance of false seedbed as weed management of annual weeds belonging to Lolium spp. which is directly associated with herbicide resistance patterns (Kotoula-Syka and Tal, 2000; Travlos et al., 2016). The role of false seedbed on the management of annual weeds should be further evaluated since it has been observed to provide the competitiveness of barley (Hordeum vulgare L.) against Lolium rigidum (L.) (Kanatas et al., 2020). In addition, false seedbed reduced growth rate of $L$. temulentum as compared to normal seedbed preparation (Kumar et al., 2013) and a technique similar to false seedbed reduced the percentage of viable seeds of Lolium perenne (L.) (Jensen, 2010). However, the results of the present study did not suggest false seedbed as an effective control method of perennial weeds. In contrast to these findings, in peanut (Arachis hypogaea L.), Johnsson and Mullinix (2000) recorded the lowest density of Cyperus esculentus (L.) in false seedbed plots where shallow tillage operations were used as weed control method.

Pendimethalin application in plots of normal seedbed resulted in significantly lower total weed dry weight per unit area. A study showed that planting vigorous cultivars into non-disturbed soils with greater available moisture could provide an opportunity to use pendimethalin as a pre-emergence herbicide for rice production (Bond et al., 2009). A concern regarding pre-emergence chemical control is the optimum timing for applying herbicides such as pendimethalin. Preplant treatments applied 2 to 5 wk were more effective against Xanthium strumarium (L.) and I. lacunosa than preplant treatments applied at planting due to a greater chance of obtaining adequate rainfall for herbicide activation and more uniform seedbed at planting (Oliver $e t$ al., 1993).

The principle of using pelargonic acid in a stale seedbed has not been investigated. However, in the present study the combination of stale seedbed and pelargonic acid decreased the density of annual weeds as compared to normal seedbed treatment. There is evidence that pelargonic acid is an effective non-selective herbicide for a wide spectrum of annual weed species and, in organic farming, its efficacy can be enhanced by food-grade organic acids (Coleman and Penner, 2008). Stale seedbed along with pelargonic acid was also more effective against perennial weeds as compared to normal seedbed, normal seedbed along with pre-emergence chemical control and false seedbed treatment. Furthermore, similar were the effects of its application in stale seedbed plots regarding total weed dry weight per unit area. These findings are in agreement with the results of a study that indicate that these non-synthetic contact herbicides can be a very effective weed control practice especially when applied to young or small weeds (Webber et al., 2012a). 
Effects of the experimental treatments on seed yield and protein content of soybean

Regarding soybean seed yield, the results of this experiment revealed the superiority of stale seedbed either along with glyphosate spray or pelargonic acid spray in comparison to the rest treatments. This finding is in agreement with the results of Bruff and Shaw (1992) who recorded that in glyphosate resistant soybean crop stale seedbed along metribuzine at $420 \mathrm{~g}$ a.i. ha ${ }^{-1}$ as pre-emergence and glyphosate at $560 \mathrm{~g}$ a.e. ha ${ }^{-1}$ as postemergence resulted in greater yield as compared to stale seedbed by tillage (Bruff and Shaw, 1992). Contradictory were the results of Heatherly et al. (1992) who indicated that glyphosate was not adequate for soybean in stale seedbed plantings, and that either pre-emergence or post-emergence herbicide applications were required for attaining maximum seed yield. However, in another study carried out in wheat crop where stale seedbed along with isoproturon application resulted in higher yield as compared to normal seedbed (Yadav et al., 1995).

In the present study the combination of stale seedbed and pelargonic acid increased soybean seed yield as compared to normal seedbed and the difference was proven as statistically significant. In addition, this treatment resulted in higher yield as compared to false seedbed and the combination of normal seedbed and pre-emergence chemical control. Pelargonic acid in commercial formulations has potential as a nonselective post-emergence contact herbicide for weeds in vegetable crops if application method and rate can be customized to individual crops to maintain weed control efficacy without reducing yields because of crop injury (Webber and Shrefler, 2007; Webber et al., 2005, 2012a). The principle of using pelargonic acid in a stale seedbed needs to be further investigated.

As it was observed in the current study, the combination of normal seedbed and pendimethalin and false seedbed treatment leaded to higher soybean yield than normal seedbed treatment. These results are in common direction with the findings of other scientists who noticed that in pea crop, yields were increased by approximately $88 \%$ with the integration of false seedbed and pendimethalin as pre-emergence chemical control in comparison with false seedbed without herbicide use (Kumar et al., 2014). Furthermore, stale seed bed at par with normal seed bed followed by triallate at $1000 \mathrm{~g} \mathrm{ha}^{-1}$ as pre-emergence chemical control have been reported to increase tillering, crop dry matter and grain yield of wheat by $21 \%$ as compared to normal seed bed (Kumar et al., 2003).

One of the observations of the current experiment was that false seedbed treatment resulted in higher soybean seed yield as compared to the adoption of normal seedbed with no herbicide application. This result comes in agreement with the finding of other scientists who noticed that in sesame crop, yield was by $48 \%$ increased when adopting false seedbed technique instead of conventional method of land preparation (Rasmussen and Ascard, 1995). Higher yield has also been recorded in peanut by using false seedbed as weed control method (Johnson and Mullinix, 2000), as well. In Greece, false seedbed has been proven to be a very effective control method not only against annual weed species when combined post-emergence chemical control resulted in a great increase in barley grain yield as compared to direct sowing of barley (Kanatas et al., 2020).

Adopting false seedbed technique instead of normal seedbed preparation did not result in significantly higher protein content in the seeds of soybean. In addition, the protein content in soybean seeds was greater in plots where normal seedbed was followed by pendimethalin spray as compared to plots of normal seedbed where no herbicide was used but the difference was not proven as statistically significant. However, Peer $e t a l$. (2013) recorded approximately $11 \%$ more protein content in soybean seeds by applying pendimethalin at 1000 $\mathrm{g}$ a.i. ha ${ }^{-1}$ integrated with hand weeding once over that given by weedy check. The results of this experiment suggest also that stale seedbed combined either with the glyphosate spray or pelargonic acid spray can be beneficial for soybean protein content. The increased protein content in soybean seeds could be attributed to better nitrogen content under these treatments which favoured effective elimination of weeds. The possible effects of false and stale seedbed on crops that are cultivated as protein-rich food sources set a new unexplored area of great interest. 


\section{Conclusions}

The results of the current study carried out in soybean revealed that adopting stale seedbed technique along either with glyphosate or pelargonic acid application can be a very effective strategy against weed infestation in soybean and result in higher yields as compared to the adoption of conventional seedbed preparation. When adopting stale seedbed technique, applying pelargonic acid poses as an eco-friendly effective alternative of glyphosate with similar efficacy especially against annual weeds. Stale seedbed by glyphosate seems to be superior to the application of pendimethalin as pre-emergence chemical control in normal seedbeds. In false seedbed plots important weed species densities were lower as compared to normal seedbed plots. To conclude, the role of either false or stale seedbed technique, as part of integrated weed management seems promising and ought to be further investigated in various crops, soil types and climatic changes. The lack of new herbicide modes of action and the withdrawal of many of the available active ingredients due to the impact of European Union (EU) legislation on pesticides aggravates the situation related to herbicide resistance patterns indicating that alternative weed control strategies need to be evaluated for their efficacy against weed infestation and their effect on each crop's final yields.

\section{Conflict of Interests}

The authors declare that there are no conflicts of interest related to this article.

\section{References}

Ameena M, Kumari VL, George S (2006). Integrated management of purple nutsedge (Cyperus rotundus L.) in okra. Indian Journal of Weed Science 38:81-85.

Barberi P (2003). Preventive and cultural methods for weed management. In: Labrada R(Ed). Weed management for developing countries. FAO Plant Production and Protection Paper 120 pp 179-194.

Bond JA, Walker TW, Koger CH (2009). Pendimethalin applications in stale seedbed rice production. Weed Technology 23:167-170.

Bruff SA, Shaw DR (1992). Tank-mix combinations for weed control in stale seedbed soybean (Glycine max). Weed Technology 6:45-51.

Coleman R, Penner D (2008). Organic acid enhancement of pelargonic acid. Weed Technology 22:38-41.

Cousens R, Mortimer M (1995). Dynamics of weed populations. Cambridge University Press, Cambridge.

Dogan MN, Ünay A, Boz Ö, Ögüt D (2009). Effect of pre-sowing and pre-emergence glyphosate applications on weeds in stale seedbed cotton. Crop Protection 28:503-507.

Food and Agriculture Organization of the United Nations (2018). FAOSTAT statistical database. http://www.fao.org/faostat/en/\#data/QC

Hartman GL, West ED, Herman TK (2011). Crops that feed the world 2. Soybean-worldwide production, use, and constraints caused by pathogens and pests. Food Security 3:5-17.

Heatherly LG, Elmore CD, Wesley RA (1992). Weed control for soybean (Glycine max) planted in a stale or undisturbed seedbed on clay soil. Weed Technology 6:119-124.

Hydrick DE, Shaw DR (1995). Non-selective and selective herbicide combinations in stale seedbed (Glycine max). Weed Technology 9:158-165.

Jensen PK (2010). Longevity of seeds of Poa prattensis and Lolium perenne as affected by simulated soil tillage practices and its implications for contamination of herbage seed crops. Grass and Forage Science 65(1):85-91.

Johnson WC, Mullinix BG (1995). Weed management in peanut using stale seedbed techniques. Weed Science 43:293-297.

Jones RE, Medd RW (2000). Economic thresholds and the case for longer term approaches to population management of weeds. Weed Technology 14:337-350. 
340

Kanatas PJ, Travlos IS, Gazoulis J, Antonopoulos N, Tsekoura A, Tataridas A, Zannopoulos S (2020). The combined effects of false seedbed technique, post-emergence chemical control and cultivar on weed management and yield of barley in Greece. Phytoparasitica 1-13.

Kotoula-Syka E, Tal A, Rubin B (2000). Diclofop-resistant Lolium rigidum from northern Greece with cross-resistance to ACCase inhibitors and multiple resistance to chlorsulfuron. Pest Management Science 56:1054-1058.

Kumar D, Angiras NN, Rana SS (2003). Influence of seed bed manipulations and herbicides on leaf area index and growth rate of wheat and associated weeds. Himachal Journal of Agricultural Research 29:1-10.

Kumar D, Angiras NN, Singh Y, Rana SS (2005). Influence of integrated weed management practices on weed competition for nutrients in wheat. Indian Journal of Agricultural Research 39:110-115.

Kumar ST, Rana SS, Kumar SR (2014). Response of pea (Pisum sativum L.) to levels of phosphorus in relation to integrated weed management. Himachal Journal of Agricultural Research 40:118-125.

Lanie AJ, Griffin JL, Vidrine PR, Reynolds DB (1994). Weed control with non-selective herbicides in soybean (Glycine max) stale seedbed culture. Weed Technology 8:159-164.

Lonsbary SK, O’Sullivan J, Swanton CJ (2003). Stale-seedbed as a weed management alternative for machine-harvested cucumbers (Cucumis sativus). Weed Technology 17:724-730.

Merfield CN (2013). False and stale seedbeds: the most effective non-chemical weed management tools for cropping and pasture establishment. The BHU Future Farming Centre, Lincoln.

Oerke EC (2006). Crop losses to pests. The Journal of Agricultural Science 144(1):31-43.

Oliver LR, Klingaman TE, McClelland M, Bozsa RC (1993). Herbicide systems in stale seedbed soybean (Glycine max) production. Weed Technology 7:816-823.

Patil B, Reddy VC, Ramachandra PTV, Shankaralingappa BC, Devendra R, Kalyanamurthy KN (2013). Weed management in irrigated organic finger millet. Indian Journal of Weed Science 45:143-145.

Peer FA, Hassan B, Lone BA, Qayoom S, Ahmad L, Khanday BA, ... Singh G (2013). Effect of weed control methods on yield and yield attributes of soybean. African Journal of Agricultural Research 8:6135-6141.

Pline WA, Hatzios KK, Hagood ES (2000). Weed and herbicide-resistant soybean (Glycine max) response to glufosinate and glyphosate plus ammonium sulfate and pelargonic acid 1. Weed Technology 14:667-674.

Rasmussen J, Ascard J (1995). Weed control in organic farming systems. In: Glen DM, Greaves MP, and Anderson HM (Eds). In: Ecology and integrated farming systems). John Wiley \& Sons Ltd, Bristol pp 49-67.

Riemens MM, Van Der Weide RY, Bleeker PO, Lotz LAP (2007). Effect of stale seedbed preparations and subsequent weed control in lettuce (cv. 'Iceboll') on weed densities. Weed Research 47:149-156.

Sharma SK, Pandey DK, Ganagwar KS, Tomar OK (2004). Weed control in direct, dry-seeded rice in India: comparison of seedbed preparation and use of pendimethalin. International Rice Research Notes 29:30-31.

Sindhu PV, Thomas CG, Abraham CT (2010). Seed bed manipulations for weed management in wet seeded rice. Indian Journal of Weed Science 42:173-179.

Székács A, Darvas B (2018). Re-registration challenges of glyphosate in the European Union. Frontiers in Environmental Science 6:78.

Travlos IS, Tabaxi I, Papadimitriou D, Bilalis D, Chachalis D (2016). Lolium rigidum Gaud. biotypes from Greece with resistance to glyphosate and other herbicides. Bulletin UASVM Horticulture 73:1-3.

Veeramani A, Prema P, Guru G (2006). Effect of pre- and post-sowing weed management on weeds and summer irrigated cotton. Asian Journal of Plant Science 5:174-178.

Webber III CL, Shrefler JW (2007). Pelargonic acid weed control: concentrations, adjuvants, and application timing. Proceedings of the 26th Oklahoma-Arkansas Horticultural Industry Show 145-148.

Webber III CL, Shrefler JW, Brandenberger LP, Davis AR (2012a). AXXE • (pelargonic acid) and Racer ${ }^{\bullet}$ (ammonium nonanoate): Weed control comparisons. Extension Publications 1-4.

Webber III CL, Shrefler JW, Langston VB (2005). Weed control with pelargonic acid (2004) lane Oklahoma. In: Brandenberger L, Wells L. (Eds). 2004 Vegetable weed control studies. Oklahoma State Univ. Div. Agr. Sci. Natural Resources Dept. Hort. Landscape Architecture MP-162 pp 40-42. 
The journal offers free, immediate, and unrestricted access to peer-reviewed research and scholarly work. Users are allowed to read, download, copy, distribute, print, search, or link to the full texts of the articles, or use them for any other lawful purpose, without asking prior permission from the publisher or the author.

(c) (i)

License - Papers published in Notulae Botanicae Horti Agrobotanici Cluj-Napoca are Open-Access, distributed under the terms and conditions of the Creative Commons Attribution (CC BY) License.

(c) Articles by the authors; UASVM, Cluj-Napoca, Romania. The journal allows the author(s) to hold the copyright/to retain publishing rights without restriction. 